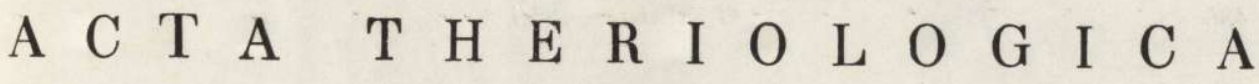 VOL. XI, 23: 485-496.

\section{Studies on the European Hare. XIII. Food Preference in Relation to Trees' Branches Experimentally Placed on the Ground}

[With 3 Tables, 4 Figs. \& 1 Plate]

\begin{abstract}
A study was made of the food preferences of heres (Lepus europaeus $\mathrm{Pa} 11 \mathrm{as}, 1778)$ in relation to branches of 12 of the commonest genera (and species) of trees found in hunting areas, placed for the purposes of the experiment on the ground, assessing the degree to which the branches were bitten according to a 7-degree scale from 0 to 6 ; a total of 3456 such assessments were made. Calculation of the significance of differences between mean assessments of degree to which the species examined were bitten permitted of dividing them into the following groups: (1) most readily bitten - Malus domestica B or k h., 1803; Salix alba L. ,1753; Crataegus monogyna J a c q., 1775; Populus tremula L., 1753; (2) moderately bitten - Robinia pseudacacia L., 1753; Quercus robur L., 1753; Fraxinus excelsior L., 1753; Pinus silvestris L., 1753; Tilia cordata M ill., 1768 and Tilia platyphyllos Scop., 1772; (3) only slightly bitten - Euro-American poplar from the black poplar section (Aigeiros Duby) - probably the Dutch poplar (Populus $x$ euramericana cultivar "Marilandica" Poiret in L a m a r c k, 1816) and Alnus glutinosa (L.) G a e r tn., 1791; (4) very slightly bitten - elder, Sambucus nigra L., 1753. It was found that the study method used reveals distinct differences in hares' food preferences in relation to the branches of the species of trees examined, and can be applied to similar tests with other species of trees of considerable importance in certain areas as food for game animals, e.g. Salix caprea, Carpinus betulus, Sorbus aucuparia.
\end{abstract}

\section{I. - INTRODUCTION}

Quantitative differences, even relative ones, in the food preferences of hares in relation to branches of different species of trees have not so far been investigated. There are no articles on this problem in either Polish or foreign literature.

Recommendations that branches of trees should be placed on the ground as food for hares (Lepus europaeus P a llas, 1778) during the winter are to be found in hunting literature (Kokeš, 1948; B o h u s z, 
1953; Budzyński, 1953; M üller-Using, 1954; P a s ławski, 1956), which emphasise that this operation is of considerable importance in hare breeding. Choice of species of trees for this purpose, based on definite figures, may increase the effectiveness of such measures.

Such figures, obtained in a way which would permit of making further comparative investigations, might also form the initial step in studies of the regularities defining the position of certain species of trees in order of preference, and also a contribution to our knowledge of the biology of so common a species as is the hare.

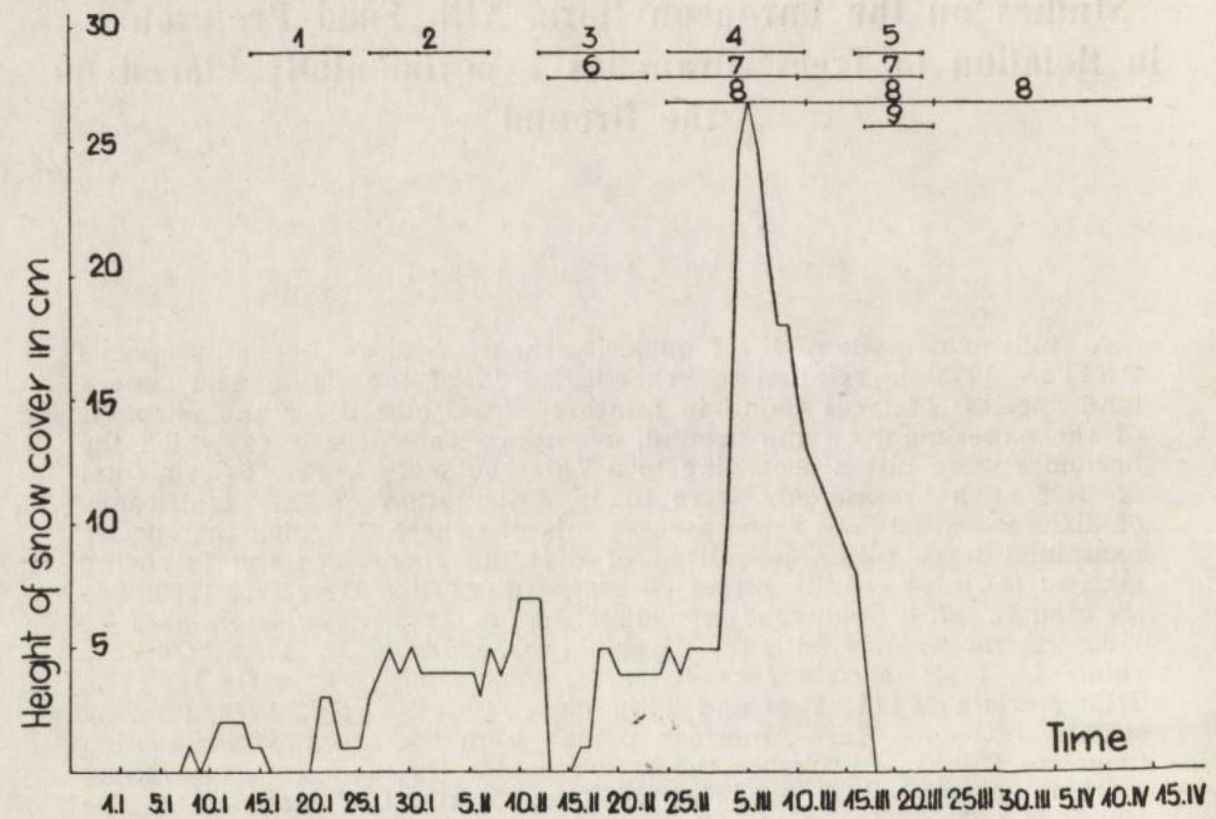

Fig. 1. Thickness of snow cover during study period and arrangement of squares in time.

$1,2, \ldots 9-$ numbers of squares (see Table 1 ).

For these reasons the present study has been aimed at finding and testing a way of determining the food preferences of hares in relation to tree branches placed on the ground and of making a list of the preference shown for 12 chosen species.

\section{CONDITIONS OF THE EXPERIMENT}

Field studies were made in the winter of $1964 / 65$ in the area belonging to the Research Station of the Polish Hunting Association at Czempin, in the Poznan province.

This is an area left by bottom moraine, flat, with slight local eminences. 
Numerous high wind-breaks, with fairly dense undergrowth, are scattered over the fertile fields, which form a large stretch of uniform crops.

The numbers of hares in the study area did not differ markedly from the average numbers for Czempin for 1964, calculated at about 40 hares/100 ha (A n d r z ejewski \& Jezierski, 1966).

During the experiment the thickness of the snow covering, which should affect the degree to which the tree shoots are bitten by hares (Dinesman, 1960), was slight (Fig. 1): from Jan. 1st to March 2nd snow was on an average $2.7 \mathrm{~cm}$ deep and the branches laid out for the hares always protruded above the snow; relatively considerable increase in depth took place from March $3 \mathrm{rd}$ to $17 \mathrm{th}$, on an average up to $14.4 \mathrm{~cm} ; 33$ of the branches (i. e. $2.5 \%$ of the total number) were then covered by snow. These fluctuations in depth of snow covering (from zero and minimum to considerable) permitted of assuming that the experiment was carried out under snow conditions average for this particular area.

The period of preliminary tests of the degree to which hares feed on tree branches lasted from December 10th 1964 to January 15th 1965. Observations were made of the branches of 18 species of trees during this period.

In order to determine the hares' food preferences 12 species of the commonest trees in the hunting area were chosen, which for this reason may be of great importance in game management. These were:

A - Malus domestica B or k h., $1803^{1}$ ), B - Tilia cordata Mi11., 1768 ^), C - Crataegus monogyna J a c q., 1775, D - Fraxinus excelsior L., 1753, E - Salix alba L., $1753^{3}$ ), F - Pinus silvestris L., 1753, G - Populus $\times$ euramericana cultivar "Marilandica", Poiret in Lamarck, $1816^{4}$ ), H - Populus tremula L., 1753, I Quercus robur L., 1753, J - Robinia pseudacacia L., 1753, K - Sambucus nigra L., 1753, L - Alnus glutinosa (L.) G a e r tn., 1791.

Branches measuring on an average about $1.5 \mathrm{~m}$ in length, usually ending in a certain number of apical shoots (Plate XV, Photo 1) were laid out on the ground during the period from January 14th to April 15th 1965 on 4 stations (Table 1) situated at distances of about $1-3 \mathrm{~km}$ from each other - I and III on winter corn, II and IIIA on ploughland.

The branches were arranged in a Latin Square (Fig. 2). In each row of this square one branch of all the 12 species of trees tested was laid on the ground at intervals of about 10 steps (approximately $8 \mathrm{~m}$ ), each species was therefore repeated

1) The majority of the species of trees were identified personally by the author, and by D. Wróblewska, M. Sc. of the Department of Plant Systematics and Geography of Warsaw Universiy.

${ }^{2}$ ) A certain number of the branches laid out belonged to the species Tilia platyphyllos Scop., 1772; identified with the co-operation of W. Jezierski, M. Sc. from the Research Station of the Polish Hunting Association at Czempin, and $\mathrm{S}$. Z a jąc z k owski, M. Sc. from the Department of Poplar Selection and Culture of the Forestry Research Institute in Warsaw.

3) Hybrid with considerable predominance of the Salix alba type.

$\left.{ }^{4}\right)$ Identification by S. He jmanowski, M. Sc., of the Department of Poplar Selection and Culture of the Forestry Research Institute in Warsaw; the identification is provisional, completely exact identification is possible after vegetative culture of specially cut branches, the so-called cuttings; - the poplar described in the study as Dutch - "Marilandica" undoubtedly belongs to the black poplar section (Populus L., 1737 Sectio Aigeiros Duby). The Latin names of this poplar are given after the following authors: $\mathrm{H}$ e j ma now ski S. (1964): Poplar thickets and nurseries, PWRiL, Warsaw; Houtzagers, G. (1941): Die Gattung Populus und ihre forstliche Bedeutung. Vrl, M. u. H. Schaper, Hannover. 
12 times in the rectangle, each time in a different place in the row and in a different combination of species adjacent to it. This arrangement ensured uniform probability of the hares' contacting the branches, with maximum evenness of mixture of species.

Assessment of the degree to which the branches had been bitten by hares was made from $1-3$ weeks after the day on which they had been laid out, arranging them in order according to a 7-degree scale, based on subjective estimates (Table 2). The degree to which the ends of the shoots and bark had been bitten were estimated separately in order to increase the degree to which the estimates were comparable; this degree is greater in material of one kind (e. g. bark: bark) and smaller in mixed material (i. e. shoots : bark or vice versa).

Table 1.

Latin squares set out during the study period.

\begin{tabular}{|c|c|c|c|c|}
\hline $\begin{array}{c}\text { Station } \\
\text { No. }\end{array}$ & $\begin{array}{c}\text { Square } \\
\text { No. }\end{array}$ & $\begin{array}{l}\text { Period during which } \\
\text { branches were laid } \\
\text { out (months) }\end{array}$ & $\begin{array}{l}\text { Branches } \\
\text { remained on the } \\
\text { ground in days }\end{array}$ & $\begin{array}{c}\text { Sum total } \\
\text { of estimates } \\
\text { in square } \\
\text { (shoots + bark) }\end{array}$ \\
\hline I & $\begin{array}{l}1 \\
2 \\
3 \\
4 \\
5\end{array}$ & 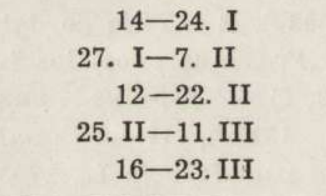 & $\begin{array}{r}10 \\
11 \\
10 \\
14 \\
7\end{array}$ & $\begin{array}{r}145 \\
65 \\
100 \\
191 \\
78\end{array}$ \\
\hline II & $\begin{array}{l}6 \\
7\end{array}$ & $\begin{array}{c}\text { 13-23. II } \\
\text { 24. II-10. III }\end{array}$ & $\begin{array}{l}10 \\
14\end{array}$ & $\begin{array}{r}85 \\
165\end{array}$ \\
\hline III & 8 & 25. II-11. III & 14 & 167 \\
\hline JIIA & 9 & $17-24 . \mathrm{III}$ & 7 & 46 \\
\hline $\begin{array}{l}\text { Control } \\
\text { squares }\end{array}$ & $\begin{array}{l}7 \\
8 \\
8\end{array}$ & $\begin{array}{r}10-23 . \text { III } \\
11-24 . \text { III } \\
24 . \mathrm{III}-15 . \mathrm{IV}\end{array}$ & $\begin{array}{l}13 \\
13 \\
22\end{array}$ & $\begin{array}{l}224 \\
201 \\
260\end{array}$ \\
\hline
\end{tabular}

The methods described here belong to the group of methods known as "choice tests" (Chitty \& Southern, 1954). The version using the Latin Square for arrangement of bait for hares under field conditions was elaborated in the Game Animals Department of Institute of Ecology of the Polish Academy of Sciences. When drawing up the scale of estimates the scales used in phytosociology were used as models (Braun-Blanquet, 1921, cited after Szafer, 1959).

\section{RESULTS}

Results obtained from 9 Latin Squares were used to ascertain the food preference of hares for branches of the species of trees tested (Table 1). In order to determine the errors in the method a repeat estimate was made of square no. 7 - once, and square no. 8 - twice (control square - 
Table 1). A total number of 3456 estimates was therefore made (12 squares $\times 144$ points $\times 2$ estimates: for shoots and for bark $=3456$ ).

Estimates were summarised for the given species and the order of choice of species determined according to decreasing values of summarised estimates - separately for shoots and bark (Table 3). It was found that differences in the order of preferences for shoots and bark

\begin{tabular}{|c|c|c|c|c|c|c|c|c|c|c|c|}
\hline L & I & E & $\mathrm{K}$ & H & $\mathrm{J}$ & B & F & C & D & A & G \\
\hline $\mathrm{K}$ & F & $\mathrm{J}$ & $\mathrm{H}$ & B & I & E & G & $\dot{\mathrm{A}}$ & L & D & C \\
\hline $\mathbf{J}$ & A & $\mathrm{H}$ & B & I & L & C & D & $\mathrm{E}$ & G & F & $\mathrm{K}$ \\
\hline I & $\mathrm{H}$ & G & $\mathrm{J}$ & C & A & L & $\mathrm{K}$ & D & $\mathrm{E}$ & $\mathrm{E}$ & $\mathrm{F}$ \\
\hline $\mathrm{H}$ & $\mathrm{E}$ & D & G & L & B & A & I & $\mathrm{K}$ & $\mathrm{F}$ & C & $\mathrm{J}$ \\
\hline G & $\mathrm{K}$ & I & C & A & D & $\mathrm{J}$ & B & $\mathrm{F}$ & $\mathrm{H}$ & L & E \\
\hline F & $\mathrm{J}$ & L & E & $\mathrm{K}$ & C & $\mathrm{H}$ & A & G & I & B & D \\
\hline E & D & F & L & $\mathrm{J}$ & G & $\mathrm{K}$ & C & $\mathrm{H}$ & A & I & B \\
\hline D & C & B & A & G & E & F & $\mathrm{J}$ & L & $\mathrm{K}$ & $\mathrm{H}$ & I \\
\hline C & G & A & I & E & $\mathrm{K}$ & D & $\mathbf{L}$ & B & $\mathrm{E}$ & $\mathrm{J}$ & $\mathrm{H}$ \\
\hline B & L & $\mathrm{K}$ & $F$ & D & $\mathrm{H}$ & I & $\mathrm{E}$ & $\mathrm{J}$ & C & G & A \\
\hline A & B & C & D & E & F & G & $\mathrm{H}$ & I & $\mathrm{J}$ & K & L \\
\hline
\end{tabular}

Fig. 2. Diagram of Latin square.

- limit of zones of the square - outer and inner, accepted for purposes of the investigations,

line enclosing stations in immediate vicinity of apple tree branches (indicated by letter A), given as example,

A, B, C, ... identification of species of trees used in the experiment (see text: section 2: Conditions of experiment).

are relatively the greatest for certain species occupying foremost places in the preference orders, e. g. willow - the shoots of which are more readily eaten than the bark. The reverse phenomenon is observed in the case of ash - the shoots are only nibbled, while the bark is intensively gnawed (Table 3 ).

In the case of certain species the extent to which the shoots are bitten does not differ from that of the bark, e. g. in the case of Crataegus, or 
Table 2.

Scale of estimates used when assessing the degree to which the branches were bitten by the hares.

\begin{tabular}{|c|c|}
\hline Estimate & Details of estimate \\
\hline 0 & no traces of feeding \\
\hline 1 & $\begin{array}{l}\text { perceptible traces of gnawing but to slight extent only; single } \\
\text { shoots bitten off or incisor marks on bark }\end{array}$ \\
\hline 2 & $\begin{array}{l}\text { distinct traces of gnawing; at least fair number of shoots distinctly } \\
\text { bitten or several distinct incisor marks on bark }\end{array}$ \\
\hline 3 & $\begin{array}{l}\text { branches distinctly bitten; disappearance of about } 1 / 4 \text { of the whole } \\
\text { wood mass usually gnawed by hares under natural conditions } \\
\text { (edible mass) (Photo. 1) }\end{array}$ \\
\hline 4 & $\begin{array}{l}\text { branches gnawed to medium extent, disappearance of about } 1 / 2 \text { of } \\
\text { the edible mass (Photo. } 2 \text { and } 3 \text { ) }\end{array}$ \\
\hline 5 & $\begin{array}{l}\text { branches intensively gnawed, disappearance of about } 3 / 4 \text { of the } \\
\text { edible mass }\end{array}$ \\
\hline 6 & $\begin{array}{l}\text { branches very intensively gnawed, disappearance of about the whole } \\
\text { edible mass, leaving only residue; no such assessments were made } \\
\text { in the material used for the experiments }\end{array}$ \\
\hline
\end{tabular}

Table 3.

Hares food preferences in relation to the tree branches laid out in the experiment.

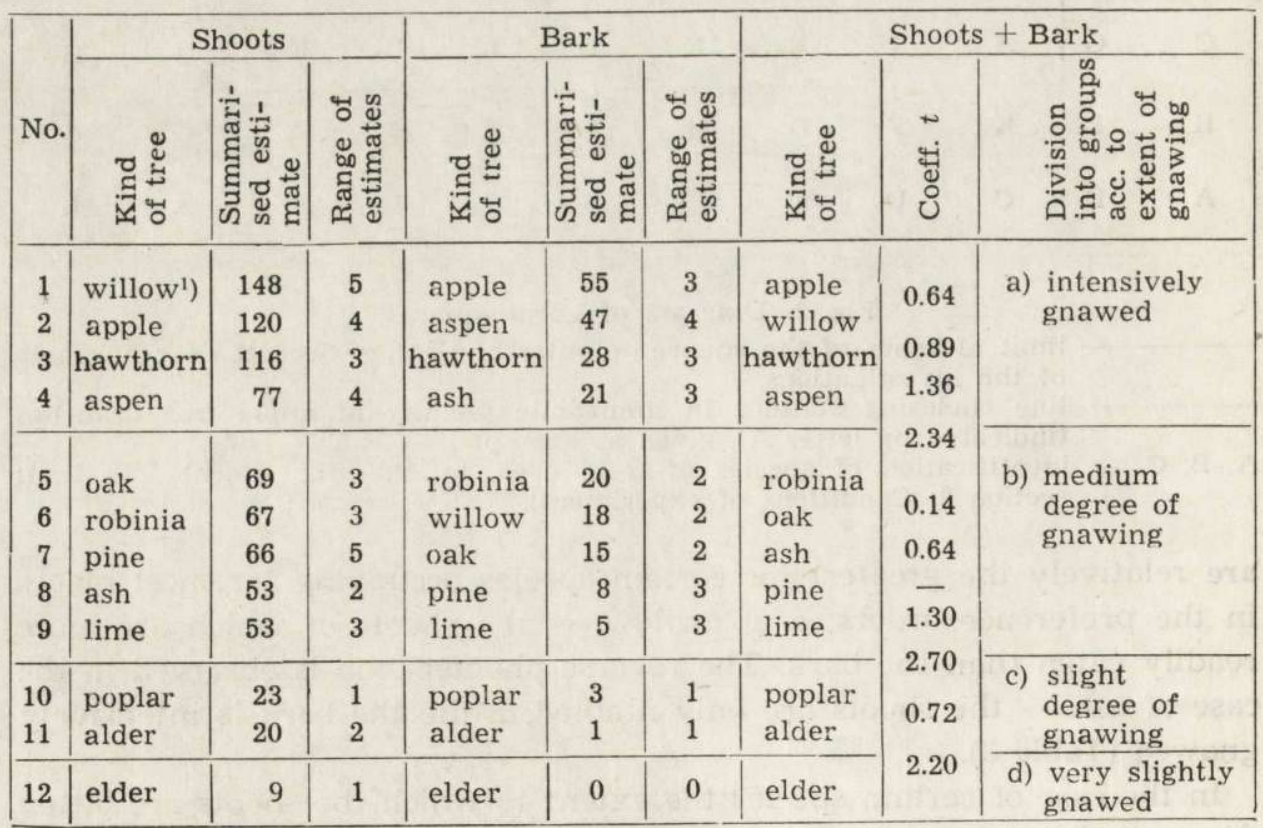

1) For identification of species see text. 
the differences are very slight, e. g. in the case of apple trees. The order of species occupying the end places in the preference list is identical in the columns for shocts and for bark. In general it was found that differences between degree to which shoots and bark are gnawed are relatively slight in the majority of the species examined.

Assessments of preferences for shoots were summed up jointly with those for bark, and the preference order for species was established according to combined assessments. The significance of differences between consecutive species in the table was checked by means of the Student test, and where differences proved significant, i. e. $t>t_{0,05}=1.97$ the groups of species were divided as follows: (a) intensively bitten ( $M a-$ lus domestica Borkh., 1803; Salix alba L., 1753; Crataegus monogyna J a c q., 1775; Populus tremula L., 1753), (b) moderately bitten (Robinia pseudacacia L., 1753; Quercus robur L., 1753; Fraxinus excelsior L., 1753; Pinus silvestris L., 1753; Tilia cordata Mill., 1768, with admixture of Tilia platyphyllos S cop., 1772), (c) slightly bitten (Populus euramericcna cultivar "Marilandica" Poiret in La ma rck, 1816 and Alnus glutinosa L., G a e r tn., 1791), (d) very slightly bitten (Sambucus nigra L., 1753).

The order of these species exhibits a high degree of agreement with some of the data given by K ok e š (1948) and other authors referred to in the introduction to this study; they do not, however, as a rule give identification of the tree species, but only the genus. Agreement of the data obtained with data given in this literature is particularly great in the case of genera of trees at the top of orders of preference (lists of preferences). The data given by these authors were, however, probably obtained by means of loose observations or compared on the basis of literature (their sources are not given) and are not therefore fully comparable.

It must be emphasised that three genera of trees: lime, poplar and alder occupied low places on the preference list, which indicates that their being given as specially suitable as branch food for hares (lime K okeš, 1948; B u dzyń ski, 1953; alder - Budzyński, 1953; soft deciduous species - among which poplar is included - $\mathrm{Pas}$ a w ski, 1956 and 1964) is unjustified.

In order to assess whether the branches from the side of the square are more intensively bitten than those from the middle calculation was made of the summarised averages of estimates of degree to which the branches in two zones were bitten: the outer $(\bar{x}=7.97)$ and inner $(\bar{y}=6.14)$, distinguished by a thick line in Fig. 2. The significance of the difference between the calculated averages determined by means of the Student test is very slight $\left(t=2.1>t_{0,05}=1.97\right)$. The location of the 
branches inside the square has only a very slight effect on the degree to which the branches are bitten by the hares, but the principle itself of the Latin square ensures that the effect is uniform on each species, and therefore does not alter the order of species on the list of preference.

In order to ascertain whether the neighbourhood of a given species with the species most readily bitten (apple) affects either the raising or lowering of its estimates, calculation was made of two averages for each species of tree: from the whole square and from the stations immediately neighbouring with apple (stations used as examples are surrounded with a dotted line on Fig. 2). It was found that all the species have lower estimates in the neighbourhood of apple in relation to estimates calculated for all the stations in the square (Fig. 3).

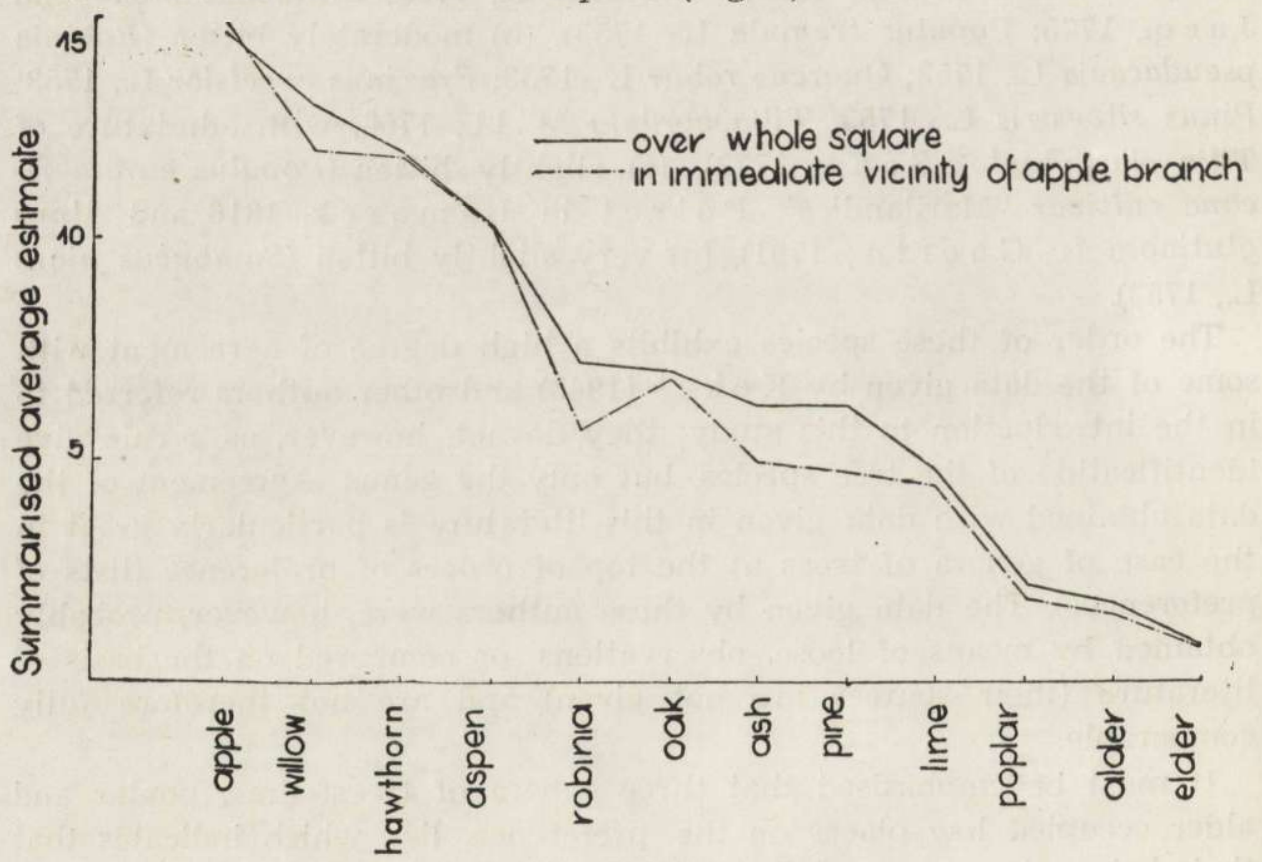

Fig. 3. Comparison of degrees of gnawing.

Columns of averages calculated for the species examined from stations situated in the neighbourhood of several other selected species did not exhibit this regularity. The estimates were lower for certain species, and higher for others in the vicinity of the species for which it was desired to determine the influence, and no single trend of differences was manifested such as was observed when the influence of apple tree branches was determined.

Criterion $\chi^{2}$ and the Student test used to estimate the significance of differences between mean estimates for each species in the whole square 
and for the stations in the immediate vicinity of apple tree branches did not, however, show that these differences are statistically significant. To sum up it may be said that the proximity of a species to a species most attractive to hares causes a slight increase in preferential differences in favour of the attractive species and tends to reduce the assessments of the species neighbouring it (Fig. 3).

The range of estimates for the given species of tree was determined by the difference betwen the extreme estimates obtained for this species.

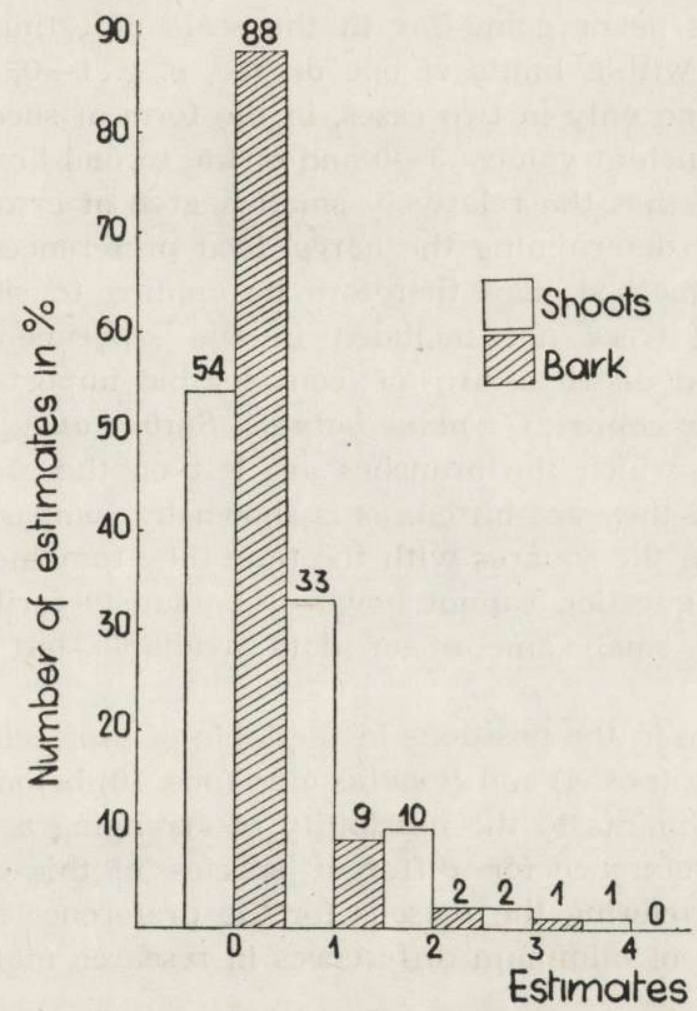

Fig. 4. Percentage distribution of estimates (explanation in text).

As might have been anticipated, according to this the species most preferred have the widest range of estimates, and the species least preferred the smallest (Table 3). The total distribution of estimates in percentages is given in Fig. 4. The fact that there is a greater percentage of low estimates in the total number of estimates indicates that intensity cf biting the branches, and therefore of its extent, was only slight during the study period. Observations of the extent to which hares gnaw branches, made outside the bounds of the experiment, but parallel to it in time, showed that this conclusion may be extended to apply not only 
to the material used in the experiment, but also in general to food consisting of branches in the ares of the Scientific Research Station at Czempin during the 1964/65 season; this fact argues in favour of branch fodder being regarded as supplementary food during the study period.

The relative error in the method of estimation was examined by making repeat assessments in squares no. 7 and 8 . The repeat estimate may be greater or equal to the preceding, but cannot be smaller; cases in which it was smaller were taken as errors.

Out of the 864 estimates taken for testing 84 were erroneous (i. e. $9.7 \%$ ) the error never going far in the scale of estimates, but almost always coming within limits of one degree, e. g. $1-0,2-1$, etc. Basic errors were found only in two cases, in the form of successive estimates of the same branch at values: $3-0$ and of the second branch $2-0$. It was therefore found that the relatively small degree of error in the method used permits of determining the hares' food preferences with sufficient accuracy; this method may therefore be applied to similar tests with other species of trees not included in the experiment described, but which in certain districts are of considerable importance as food for game, e. g. Salix caprea, Carpinus betulus, Sorbus aucuparia.

The time for which the branches are left on the ground affects the degree to which they are bitten, as is shown by comparison of summarised estimates in the squares with the time they remained on the ground (Table 1); this question cannot however be satisfactorily dealt with on the basis of the small amount of data available, but requires further investigation.

The difference in the positions in the table of preferences (Table 3 ) for Populus tremula (pos. 4) and Populus alba (pos. 10) belonging to the same genus Populus, points to the possibility of arranging a distinctly different order of preference for different species of this genus and to the prospect of discovering the reasons for the preference shown (according to the principle of minimum differences in research material).

Acknowledgements: It is my pleasant duty to thank Dr. W. Grodzin ski of the Department of Genetics and Organic Evolution of the Jagiellonian University, Cracow, and W. Jezierski, M. Sc., of the Research Station of the Polish Hunting Association at Czempin, for the valuable advice and assistance they gave me during the preparation of this study.

\section{REFERENCES}

1. Andrzejewski R. \& Jezierski W., 1966: Studies on European Hare. XI. Estimation of population density and attempt to plan the yearly take of hares. Acta theriol., 11, 21: 433-438.

2. Bohusz J., 1953: Urządzanie łowiska polnego. Państw. Wyd. Roln. i Leśń.; 1-105. Warszawa. 
3. B u dzy ńs k i E., 1953: Zając. Hodowla i polowanie. Państ. Wyd. Roln. i Leśn.: 1-67. Warszawa.

4. Dinesman L. G., 1960: Vlijanie glubiny snega na vrednuju dejatel'nost' zajca-rusaka $v$ južnyh rajonah evropejskoj časti SSSR. Tr. In-ta Lesa, 48: 189-199.

5. Chitty D. \& Southern H. N., 1954: Control of rats and mice. Clarendon Press, $1-3$. Oxford.

6. K ok eš O., 1948: Zajic, jeho život, chov a lov. Vydáno pečí myslivecké jednoty Zemského svazu Cechy. Studentské knihtiskárny v Praze, 1-254. Praha.

7. M üller-Using D., 1954: Diezels Niederjagd. Paul Parey, 1-367. Hamburg und Berlin.

8. Pasławski T., 1956: Dokarmianie zwierząt łownych. Państw. Wyd. Roln. i Leśn.: 1-87. Warszawa.

9. Pas lawski T., 1965: Łowiectwo dla leśników i myśliwych. Państw. Wyd. Roln. i Leśn.: 1-319. Warszawa.

10. Sz a f e r W., 1959 (ed.): Szata roślinna Polski. Państw. Wyd. Nauk., 1: 1-586. Warszawa.

Received, January 22, 1966.

Polish Academy of Sciences,

Institute of Ecology,

Warszawa, Nowy Swiat 72 .

\section{EXPLANATION OF PLATE}

Plate XV.

Phot. 1. Branches of trees laid out in the field.

Phot. 2. Branches distinctly gnawed (estimated degree 3).

Phot. 3. Branches gnawed to medium extent (estimate degree 4).

\section{Gustaw MATUSZEWSKI}

BADANIA NAD ZAJĄCEM SZARAKIEM. XIII. WYBIORCZOSĆ POKARMOWA W STOSUNKU DO EKSPERYMENTALNIE WYKŁADANYCH GAEĘZI DRZEW

\section{Streszczenie}

W Czempiniu, woj. poznańskie, w okresie od 14. I. do 15. IV. 1965 r. badano wy biórczość pokarmową zajęcy w stosunku do eksperymentalnie wykładanych gałęzi 12 najpospolitszych w lowisku rodzajów (i gatunków) drzew. Gałęzie układano w otwartym terenie w schemacie kwadratu łacińskiego, w odległościach ca $8 \mathrm{~m}$ i po 1-3 tygodniach oceniano stopień zgryzienia przez zające w skali 7-stopniowej obejmującej oceny od 0 do 6 . Ogółem wykonano 9 kwadratów (tj. wyłożeń świeżych gałęzi); kwadrat $\mathrm{nr} 7$ oceniono powtórnie po 13 dniach a kwadrat $\mathrm{nr} 8$ dodatkowo 2 razy po 13 i 22 dniach; powtórne oceny wykonano dla określenia błędu ocen. Pędy i korę oceniano ordzielnie. 
Na podstawie obliczeń statystycznych wykonanych na materiale liczbowym obejmującym 3456 ocen stwierdzono:

1. $\mathrm{Z}$ badanych gatunków zgryzane są: a) silnie: jabłoń domowa, Malus domestica B orkh., 1803; wierzba biała, Salix alba L., 1753; głóg jednoszyjkowy, Crataegus rıonogyna J a cq., 1775; topola osika, Populus tremula L., 1753; b) średnio: robinia akacjowa, Robinia pseudacacia L., 1753; dąb szypulkowy, Quercus robur L., 1753; jesion wyniosły, Fraxinus excelsior L. 1753; sosna zwyczajna, Pinus silvestris L., 1753; lipa drobnolistna, Tilia cordata Mili., 1768 i lipa wielkolistna Tilia platyphyllos S cop., 1772; c) słabo: topola holenderska, Populus euramericana cultivar „Marilandica” i olsza czarna, Alnus glutinosa (L.) Gaertn., 1791; d) bardzo ) słabo: bez czarny, Sambucus nigra L., 1753.

2. Stopień zgryzienia gałęzi jest nieco wyższy w strefie zewnętrznej pola kwad̀ratu użytego jako schemat rozłożenia ocenianych gałęzi niż w jego strefie we-wnętrznej.

3. Gatunek najbardziej atrakcyjny dla zajęcy (jabłoń) nieznacznie obniża sto-pień zgryzienia gatunków sąsiadujących bezpośrednio z nim w kwadracie.

4. Zastosowana metcdyka jest wystarczająco dokładna dla ustalenia wybiór-. czości pokarmowej zajęcy względem badanych gatunków drzew.

5. Rozmiar zgryzania i jego intensywność są niewielkie co pozwala przypuszczać,, że w okresie badań żer gałązkowy był żerem dopełniającym a nie zasadniczym.

Ponadto uzyskane wstępne materiały wskazują na możliwość rozwiązania takich zagadnień jak zależność stopnia zgryzienia galęzi od czasu ekspozycji oraz znale-zienia przyczyn preferencji pokarmowej zajęcy względem gałęzi różnych gatun-ków drzew. 


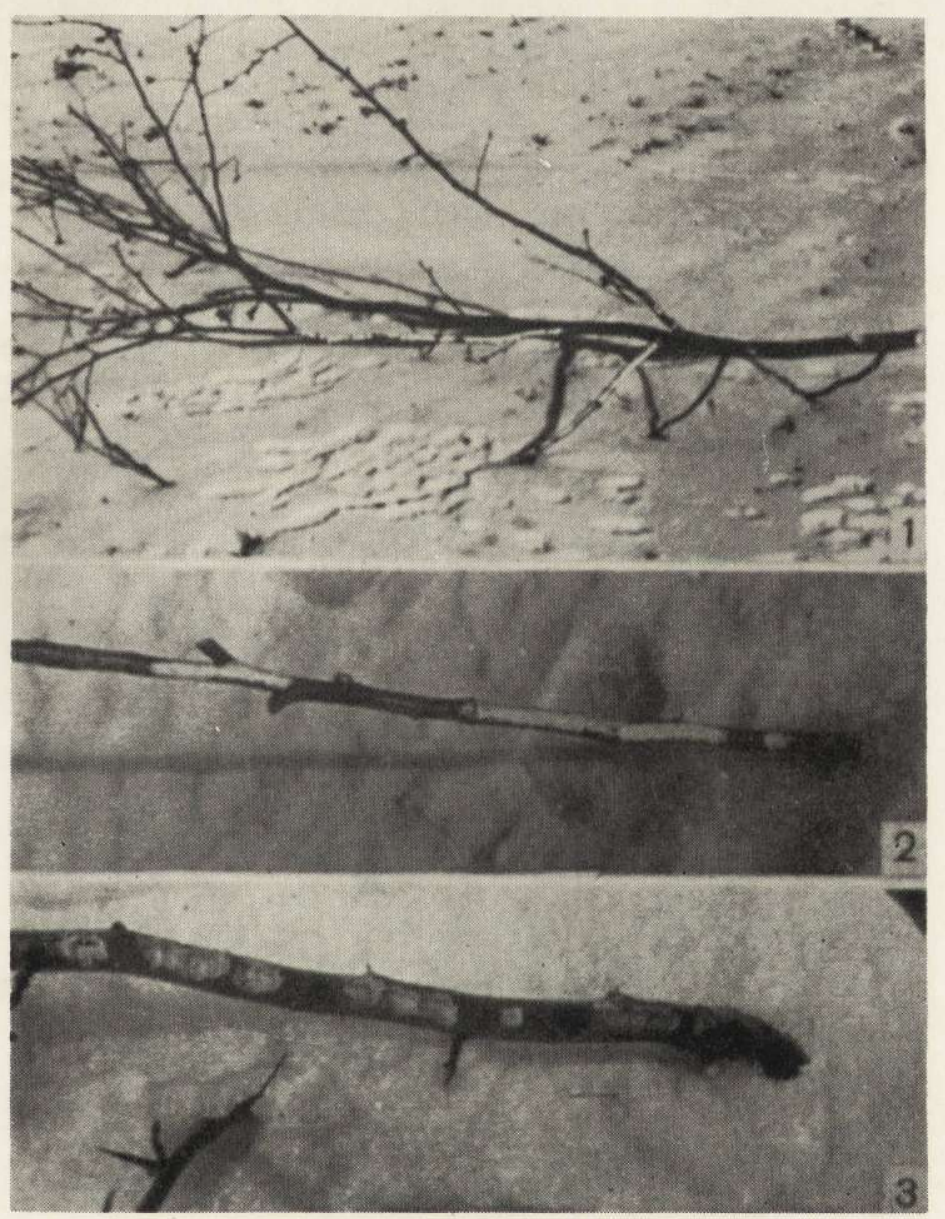




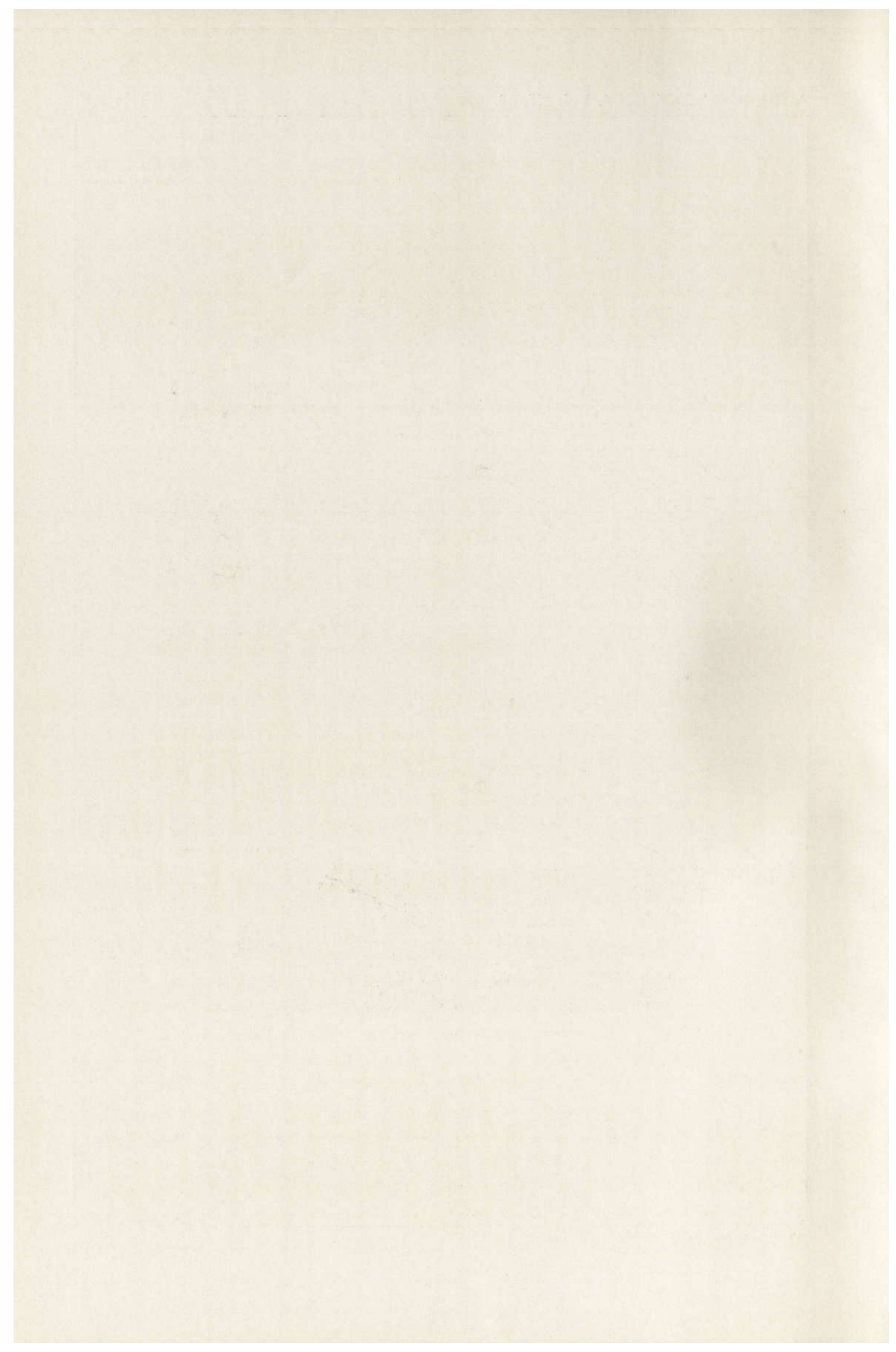

